\title{
Screening of chitinase-producing rhizosphere actinomycetes and their genetic diversity
}

\author{
ARIS TRI WAHYUDI ${ }^{1, \boldsymbol{v}}$, NAUFAL GHAZI FITHRIANSYAH ${ }^{1}$, MUHAMMAD FAIZ AMRI ${ }^{1}$, \\ JEPRI AGUNG PRIYANTO ${ }^{1}$, ABDJAD ASIH NAWANGSIH ${ }^{2}$ \\ ${ }^{1}$ Department of Biology, Faculty of Mathematics and Natural Sciences, Institut Pertanian Bogor. Jl. Raya Dramaga, Bogor 16680, West Java, Indonesia \\ Tel./fax.: 62-251-8622833. `email: ariswa@apps.ipb.ac.id. \\ ${ }^{2}$ Department of Plant Protection, Faculty of Agriculture, Institut Pertanian Bogor. J1. Raya Dramaga, Bogor 16680, West Java, Indonesia
}

Manuscript received: 21 August 2021. Revision accepted: 14 September 2021.

\begin{abstract}
Wahyudi AT, Fitriansyah NG, Amri MF, Priyanto JA, Nawangsih AA. 2021. Screening of chitinase-producing rhizosphere actinomycetes and their genetic diversity. Biodiversitas 22: 4186-4192. Soil microbial community, especially rhizosphere actinomycetes, plays an important role in protecting plants from phytopathogenic fungi by producing various agroactive compounds, including mycolytic enzymes particularly chitinase. The objective of this study was to investigate chitinase activity and analyze the diversity of family 19 chitinase genes of actinomycetes isolated from maize and soybean rhizosphere. Of fivety actinimycetes, Seventeen isolates exhibited chitinolytic activities and formed a hydrolytic zone around the colony with chitinolytic index ranging from $0.49 \pm 0.01$ to $2.15 \pm 0.69$, qualitatively tested in $0.3 \%$ chitin agar medium. Six selected isolates (ARJ 36, ARJ 81, ARJ 15 , ARK 17 , ARK 143, ARK 103) showed chitinase activities ranging from $0.157 \pm 0.04$ to $0.440 \pm 0.09 \mathrm{U} / \mathrm{mL}$, based on chitinolytic index. The production of chitinase was confirmed by the presence of family 19 chitinase encoding genes from Streptomyces sp. Some conserved regions and essential amino acid residues were also detected. This study suggests that chitinolytic actinomycetes isolated from maize and soybean rhizosphere can be studied further as biological control candidates for controlling phytopathogenic fungi.
\end{abstract}

Keywords: Chitinase, family 19 chitinase gene, rhizosphere actinomycetes, Streptomyces

\section{INTRODUCTION}

Rhizosphere microbial community lives and interacts within the area around plant roots. The community structure of these microorganisms depends on soil biotic and abiotic factors, such as plant type, soil type and conditions. Rhizosphere contains abundant organic compounds as plant exudates are necessary for microorganisms, inducing higher diversity compared to area beyond rhizosphere. Interaction between rhizosphere microorganisms and plants can offer either mutual benefits or drawbacks. Actinomycetes is an important group of bacteria that live in the rhizosphere. It is filamentous Grampositive bacteria found in both terrestrial and aquatic ecosystems. Actinomycetes, especially genus Streptomyces, is one of the largest bioactive compounds producer comprising vitamins, alkaloids, growth stimulating factors, and enzyme inhibitors (Gherbawy et al. 2012). These bacteria also play an important role in the soil as Plant Growth-Promoting Rhizobacteria (PGPR).

PGPR are bacteria that colonize rhizosphere and stimulate plant growth whether through direct or indirect mechanisms (Vejan et al. 2016). Nitrogen fixation, phosphate and mineral solubilization and the production of phytohormones, such as auxins, cytokines, and gibberellins are classified as direct mechanisms. Whereas indirect mechanisms, include stress relieving ACC deaminase enzyme production and protection against pathogen by the production of antibiotic, low molecular weight metabolites (such as HCN), lytic enzymes, and siderophores
(Gopalakrishnan et al. 2016). Streptomyces is capable of producing various agroactive compounds such as phytohormones, siderophores, antibiotics, and hydrolytic enzymes to promote plant growth (Anwar et al. 2016). Several species of actinomycetes are widely known to have an important role in the rhizosphere protecting plants from phytopathogenic fungi. Plant diseases are a major problem in crop cultivation, accounting for $10 \%$ of crop loss, one of which is caused by phytopathogenic fungi (Brzezinska et al. 2014). Gherbawy et al. (2012), reported that some Streptomyces have antifungal activity against Fusarium oxysporum, Pythium aristosporum, Colletotrichum gossypii, and Rhizoctonia solani. Cell wall degradation by chitinase is a notable means by PGPR in suppressing phytopathogenic fungi.

Chitin $\left(\mathrm{C}_{8} \mathrm{H}_{13} \mathrm{O}_{5} \mathrm{~N}\right)_{\mathrm{n}}$ is the main component of some phytopathogenic fungi cell wall (Beauvais and Latge 2018). Chitinase is a glycosyl hydrolase enzyme group that catalyze the termination of $\beta$-1,4-glycosidic bonds in chitin polymers (Oyeleye and Normi 2018). Based on amino acid sequence, chitinase is divided into families 18 and 19. Family 18 chitinase is commonly found in bacteria, fungi, viruses, animals and plants (class III and V chitinases). However, family 19 chitinase is found in plants (class I, II, IV chitinases) and some bacteria. As described by Veliz et al. (2017), family 19 chitinase is found in actinomycetes, green non-sulfur, and purple bacteria. This finding revealed that actinomycetes also produce family 19 chitinase which previously only found in plants (Gherbawy et al. 2012). Family 19 chitinase is known to have high antifungal 
activity against Rhizoctonia solani, Colletotrichum gossypii, Pythium aristosporum, and Fusarium oxysporum (Singh et al. 2021).

Fifty actinomycetes isolates, including 30 isolates from maize rhizosphere (Wahyudi et al. 2019a) and 20 isolates from soybean rhizosphere (Wahyudi et al. 2019b), have successfully been isolated. The studies reported that these isolates have growth-promoting activity and stimulate sprouts growth in vitro. These isolates also have antifungal activity against Fusarium oxysporum, a soil-borne phytopathogenic fungi (Mariastuti et al. 2018). However, the ability of these isolates to produce hydrolytic enzymes, particularly chitinase, have not been studied. This study aimed to screen soybean and maize rhizosphere actinomycetes that produce chitinase and determine their genetic diversity based on chitinase genes sequences.

\section{MATERIALS AND METHODS}

\section{Qualitative screening of chitinolytic activity}

Chitinolytic activity of all 50 actinomycete isolates was screened by observing the formation of chitinolytic zones on solid medium containing $0.3 \%$ chitin (Glesiandra 2016). These isolates were initially enriched on International Streptomyces Project (ISP) 4 medium (composition: $10 \mathrm{~g}$ soluble starch; $1 \mathrm{~g} \mathrm{~K}_{2} \mathrm{HPO}_{4} ; 1 \mathrm{~g} \mathrm{MgSO}$; $1 \mathrm{~g} \mathrm{NaCl} ; 2 \mathrm{~g}$ $\left(\mathrm{NH}_{4}\right)_{2} \mathrm{SO}_{4} ; 2 \mathrm{~g} \mathrm{CaCO}_{3} ; 17 \mathrm{~g}$ agar; $1 \mathrm{~mL}$ of trace salts solution (TSS); $1 \mathrm{~L}$ of distilled water). TSS solution consisted of $0.1 \mathrm{~g}$ FeSO4; $0.1 \mathrm{~g} \mathrm{MnCl}$; $0.1 \mathrm{~g} \mathrm{ZnSO} 4 ; 100$ $\mathrm{mL}$ of distilled water. One plug of solid culture of actinomycetes was inoculated on $0.3 \%$ chitin agar medium (composition: 3 g colloidal chitin; $1 \mathrm{~g}$ yeast extract; $1 \mathrm{~g}$ $\mathrm{KH}_{2} \mathrm{PO}_{4} ; 0.2 \mathrm{~g} \mathrm{MgSO}_{4} .7 \mathrm{H}_{2} \mathrm{O} ; 20 \mathrm{~g}$ agar; $1 \mathrm{~L}$ distilled water) and incubated for 4 days at room temperature $( \pm$ $27^{\circ} \mathrm{C}$ ). Clear zone diameter was measured and chitinolytic index was calculated using the following formula (Dawood and Mohamed 2015):

Chitinase Index $=$ clear zone diameter - colonv diameter colony diameter

\section{Quantitative test of chitinase activity}

Chitinase activity was measured based on the amount of reducing sugar (N-acetyl-D-Glucosamine) released, as described by Berini et al. (2017). Three isolates with the highest chitinolytic index were selected from each maize and soybean rhizosphere ( 6 in total). Two plugs of selected isolates were inoculated in $30 \mathrm{~mL}$ chitin broth medium $(0.3 \%$ colloidal chitin, $\mathrm{pH} 7)$ and incubated for 8 days at $37^{\circ} \mathrm{C}$ in a shaking incubator at $150 \mathrm{rpm}$ (Glesiandra 2016). After incubation, supernatant was collected as crude enzyme extract, $10 \mathrm{~mL}$ of culture broth was centrifuged at $8000 \mathrm{rpm}$ for 10 minutes at $4^{\circ} \mathrm{C}$. The enzyme reaction was performed separately as treatment, control, and blank. Treatment reaction was carried out by mixing $0.5 \mathrm{~mL}$ supernatant with $0.5 \mathrm{~mL}$ substrate $(1 \%$ colloidal chitin in $0.1 \mathrm{M}$ phosphate buffer $\mathrm{pH} 7$ ), as for control, the substrate was mixed in the last step. All treatment, control, and blank were incubated for 30 minutes at $37^{\circ} \mathrm{C}$ with shaking at 150 $\mathrm{rpm}$. The reaction was stopped by adding $1 \mathrm{~mL}$ of $3,5-$
Dinitrosalicylic acid (DNS) and immersed in boiling water for 10 minutes. Optical density was measured using a spectrophotometer at $540 \mathrm{~nm}$. Chitinase activity was calculated using formula:

$$
\begin{gathered}
\text { Chitinase activity }(\mathrm{U} / \mathrm{mL})=(\mathrm{xNAG}) \times \mathrm{DF} \times 1000 \\
\mathrm{t} \times \mathrm{w}
\end{gathered}
$$

Where:

xNAG: concentration of NAG $(\mathrm{mg} / \mathrm{mL})$

DF: dilution factor

$\mathrm{t}$ : incubation period

w: molecular weight of NAG $(221.21 \mathrm{mg} / \mathrm{mL})$

\section{Identification of the chitinase encoding gene}

Genomic DNA was extracted using Mini gDNA Bacteria Kit (Geneaid, Taiwan) following manufacturers instruction. The family 19 chitinase gene was amplified using f19atc forward and reverse primers 5'-AA GCT CGC SGC STT CCT SGC-3' and 5'-GCA CTC GAG SGC GCC GTT GAT-3', respectively (Kawase et al. 2004). Total volume of PCR mix was $50 \mu \mathrm{L}$, comprising $25 \mu \mathrm{L}$ MyTAq polymerase $2 \mathrm{x}, 5 \mu \mathrm{L}$ primer each primer $(10 \mathrm{pmol}), 4 \mu \mathrm{L}$ DNA template $(50 \mathrm{ng} / \mu \mathrm{L}), 11 \mathrm{~mL}$ nuclease free water. PCR was initiated with pre-denaturation for 5 minutes at $95^{\circ} \mathrm{C}$ and followed by 30 cycles of denaturation for 30 seconds at $95^{\circ} \mathrm{C}$, annealing for 30 seconds at $60^{\circ} \mathrm{C}$, elongation for 1 minute at $72^{\circ} \mathrm{C}$, and ended with final elongation for 10 minutes at $72^{\circ} \mathrm{C}$. PCR product was electrophoresed in $1 \%$ agarose gel in TBE (Tris-Borate-EDTA) at $70 \mathrm{~V}$ for 45 minutes. The results were visualized using UV transilluminator. Confirmed PCR products were sent to FirstBase, Malaysia for DNA sequencing. The DNA sequences were edited using SeqTrace 0.9.0. and aligned with National Center for Biotechnology Information (NCBI) GenBank database using the Basic Local Alignment Tool (BLAST) X program for gene identification. The DNA sequences were aligned with homologous sequences, CDS, other chitinase sequences, and outgroup using Clustal W. Phylogenetic tree was constructed using neighbor joining method in 1000x bootstrap using Mega X. The amino acid sequences deduced from the DNA sequences were aligned with sequences of the other family 19 chitinase for conserved region analysis.

\section{RESULTS AND DISCUSSION}

\section{Chitinase activity of rhizosphere actinomycetes}

Of the 17 actinomycetes isolates, 12 were from maize rhizosphere (ARJ) and 5 were from soybean rhizosphere (ARK), capable of producing extracellular chitinase enzymes and forming clear zone around the colony (Figure 1). The chitinolytic activity of each isolate varied with the chitinolytic index ranging from $0.49 \pm 0.01-2.15 \pm 0.69$ (Table 1). ARJ 36 showed the highest chitinolytic index, whereas 11 isolates were categorized as moderate, and 5 isolates as low activity. Three isolates each from maize and soybean rhizosphere with the highest chitinolytic index were selected for chitinase enzyme activity testing. 


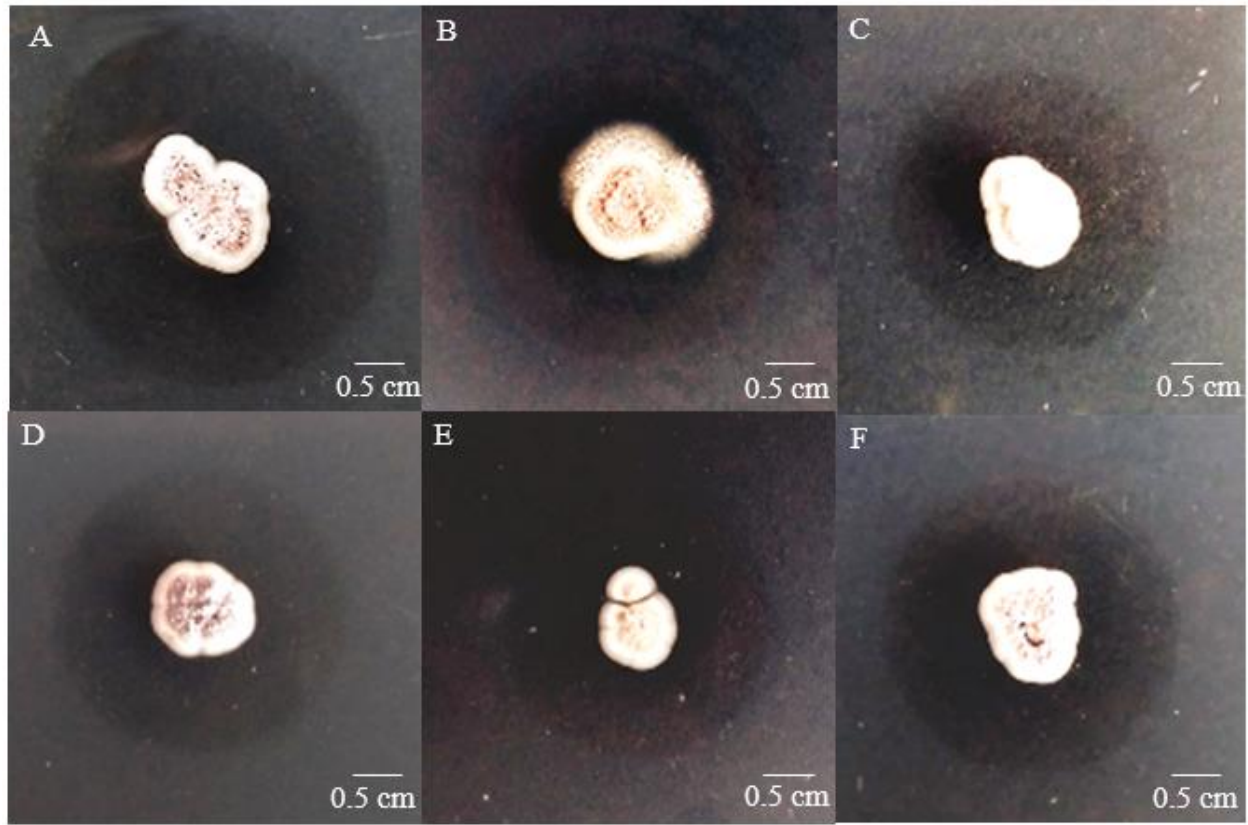

Figure 1. Chitinolytic zone of six selected rhizosphere actinomycetes isolates A. ARJ 36. B. ARJ 81. C. ARJ 15. D. ARK 17. E. ARK 143. F. ARK 103.

Table 1. Chitinolytic index of actinomycetes isolates from maize and soybean rhizosphere.

\begin{tabular}{|c|c|c|c|c|}
\hline Origin & No & $\begin{array}{l}\text { Isolate } \\
\text { code }\end{array}$ & $\begin{array}{c}* \text { Chitinolytic index } \\
\pm \text { standard deviation }\end{array}$ & $* *$ Category \\
\hline Maize & 1 & ARJ 36 & $2.15 \pm 0.69$ & +++ \\
\hline rhizosphere & 2 & ARJ 81 & $1.66 \pm 0.38$ & ++ \\
\hline & 3 & ARJ 15 & $1.56 \pm 0.12$ & ++ \\
\hline & 4 & ARJ 44 & $1.46 \pm 0.22$ & ++ \\
\hline & 5 & ARJ 32 & $1.43 \pm 0.40$ & ++ \\
\hline & 6 & ARJ 23 & $1.30 \pm 0.46$ & ++ \\
\hline & 7 & ARJ 38 & $1.02 \pm 0.27$ & ++ \\
\hline & 8 & ARJ 43 & $0.95 \pm 0.66$ & + \\
\hline & 9 & ARJ 13 & $0.70 \pm 0.44$ & + \\
\hline & 10 & ARJ 42 & $0.52 \pm 0.19$ & + \\
\hline & 11 & ARJ 22 & $0.51 \pm 0.25$ & + \\
\hline & 12 & ARJ 18 & $0.49 \pm 0.01$ & + \\
\hline Soybean & 13 & ARK 17 & $1.44 \pm 0.12$ & ++ \\
\hline rhizosphere & 14 & ARK 143 & $1.40 \pm 0.16$ & ++ \\
\hline & 15 & ARK 103 & $1.26 \pm 0.09$ & ++ \\
\hline & 16 & ARK 63 & $1.25 \pm 0.10$ & ++ \\
\hline & 17 & ARK 68 & $1.23 \pm 0.68$ & ++ \\
\hline
\end{tabular}

Note: *average of three replicate, $* *(+): \leq 1 ;(++): 1.01-1.99$; $(+++): \geq 1.99$

Chitinase activity of the six selected isolates, namely ARJ 36, ARJ 81, ARJ 15, ARK 17, ARK 143, and ARK 103 , varied from $0.157 \pm 0.04-0.440 \pm 0.09 \mathrm{U} / \mathrm{mL}$ (Figure 2). ARK 17 and ARJ 15 isolates had the highest chitinase activity with $0.440 \pm 0.09 \mathrm{U} / \mathrm{mL}$ and $0.345 \pm 0.04 \mathrm{U} / \mathrm{mL}$, respectively. The lowest i.e. $0.157 \pm 0.04 \mathrm{U} / \mathrm{mL}$ enzyme activity was each shown by ARK 81 and ARK 143 . Genetic diversity of family 19 chitinase gene. Genomic DNA of seventeen isolates were successfully extracted for family 19 chitinase gene amplification. All isolates were identified to have family 19 chitinase gene ( 385 bp) based on UV visualization of PCR products (Figure 3). BLAST.X analysis showed chitinase gene of all isolates were homologous with chitinase from Streptomyces with similarities $86-99.01 \%$ and query cover $90-99 \%$ (Table 2).

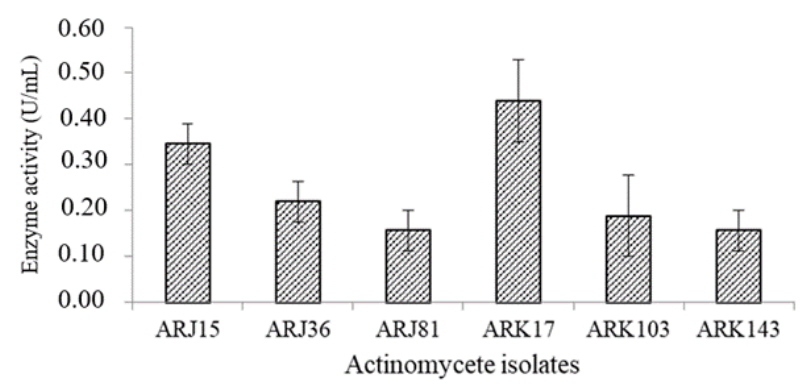

Figure 2. Chitinase activity of six selected isolates of rhizosphere actinomycetes.

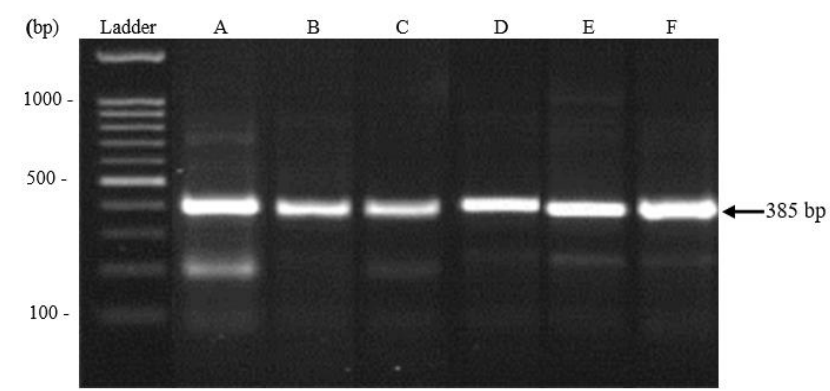

Figure 3. Gel electrophoresis of family 19 chitinase genes from six actinomycetes. A. ARJ 15. B. ARJ 81. C. ARJ 36. D. ARK 17. E. ARK 103. F. ARK 143 
Based on the phylogenetic tree, family 19 chitinase of all isolates were grouped in cluster I with chitinase $S$. griseus HUT 6037 and chitinase class IV (Figure 4). Chitinase class I (chitinase from Oryza sativa, Barley) and class II (chitinase from Jack Bean, Barley) were in cluster II. The outgroup was family 18 chitinase of Bacillus sp. Within cluster I, the isolates were separated into 2 large groups. Group 1 consists of ARK 103, ARJ 36, ARJ 32, ARJ 23, ARJ 22, and ARJ 13, while group 2 consists of
ARJ 15, ARJ 38, ARJ 42, ARJ 143, ARJ 44, ARJ 81, ARK 143, ARK 17, and ARK 63.

Alignment of the amino acid sequences with comparison sequence of the family 19 chitinase showed that 3 conserved regions commonly found in the chitinase family 19 catalytic domains, C2, C3, and C4. Four amino acid residues Gln (Q), Ser $(\mathrm{S})$, Phe $(\mathrm{F})$, and Asn $(\mathrm{N})$ which are essential in the catalytic domain were also detected in the amino acid sequence of the isolate (Figure 5).

Table 2. Identity of family 19 chitinase genes of rhizosphere actinomycetes

\begin{tabular}{|c|c|c|c|c|c|c|c|}
\hline No & $\begin{array}{l}\text { Isolate } \\
\text { code }\end{array}$ & $\begin{array}{l}\text { DNA } \\
\text { size } \\
\text { (bp) }\end{array}$ & The closest relative sequence & $\begin{array}{l}\text { Similarity } \\
(\%)\end{array}$ & E-value & $\begin{array}{l}\text { Query } \\
\text { cover } \\
(\%)\end{array}$ & $\begin{array}{l}\text { Accession } \\
\text { number }\end{array}$ \\
\hline 1 & ARJ 13 & 294 & chitinase [Streptomyces sp. E5N91 SAI-083] & 94.85 & $2 \mathrm{e}-60$ & 98 & WP_123621379.1 \\
\hline 2 & ARJ 15 & 307 & chitinase [Streptomyces sp. CS113] & 94.06 & $6 e-63$ & 98 & WP_087811127.1 \\
\hline 3 & ARJ 18 & 306 & chitinase A [Streptomyces cyaneus] & 99.01 & $2 \mathrm{e}-67$ & 99 & BAG55920.1 \\
\hline 4 & ARJ 22 & 307 & chitinase [Streptomyces rubrogriseus] & 98.04 & $5 e-68$ & 99 & WP_109028897.1 \\
\hline 5 & ARJ 23 & 308 & chitinase [Streptomyces sp. E5N91 SAI-083] & 98.00 & $6 e-66$ & 97 & WP_123621379.1 \\
\hline 6 & ARJ 32 & 308 & chitinase [Streptomyces sp. MH60] & 98.04 & $6 e-68$ & 99 & WP_104631348.1 \\
\hline 7 & ARJ 36 & 281 & MULTISPECIES: chitinase [Streptomyces] & 98.92 & $4 e-60$ & 99 & WP_059297294.1 \\
\hline 8 & ARJ 38 & 313 & chitinase [Streptomyces sp. E5N91 SAI-083] & 96.12 & $3 e-67$ & 98 & WP_123621379.1 \\
\hline 9 & ARJ 42 & 306 & chitinase 19-1 [Streptomyces coelicolor] & 94.68 & $5 e-59$ & 92 & BAA84194.1 \\
\hline 10 & ARJ 43 & 307 & ChiF, partial [Streptomyces coelicolor A3(2)] & 96.04 & $5 e-66$ & 98 & BAA75646.1 \\
\hline 11 & ARJ 44 & 307 & chitinase [Streptomyces sp. E5N91 SAI-083] & 94.06 & $1 e-64$ & 98 & WP_123621379.1 \\
\hline 12 & ARJ 81 & 314 & chitinase [Streptomyces sp. E5N91 SAI-083] & 95.15 & $1 e-66$ & 98 & WP_123621379.1 \\
\hline 13 & ARK 17 & 327 & chitinase 19-1, partial [Streptomyces coelicolor] & 86.00 & $6 e-54$ & 90 & BAA 84194.1 \\
\hline 14 & ARK 63 & 248 & MULTISPECIES: chitinase [Streptomyces] & 97.56 & $3 e-51$ & 99 & WP_059297294.1 \\
\hline 15 & ARK 68 & 247 & chitinase 19, partial [Streptomyces sp. VC-YC6636] & 95.06 & $3 e-50$ & 98 & ACJ22978.1 \\
\hline 16 & ARK 103 & 283 & MULTISPECIES: chitinase [Streptomyces] & 98.92 & $4 e-60$ & 98 & WP_059297294.1 \\
\hline 17 & ARK 143 & 307 & ChiF, partial [Streptomyces coelicolor A3] & 96.04 & $5 e-66$ & 98 & BAA75646.1 \\
\hline
\end{tabular}

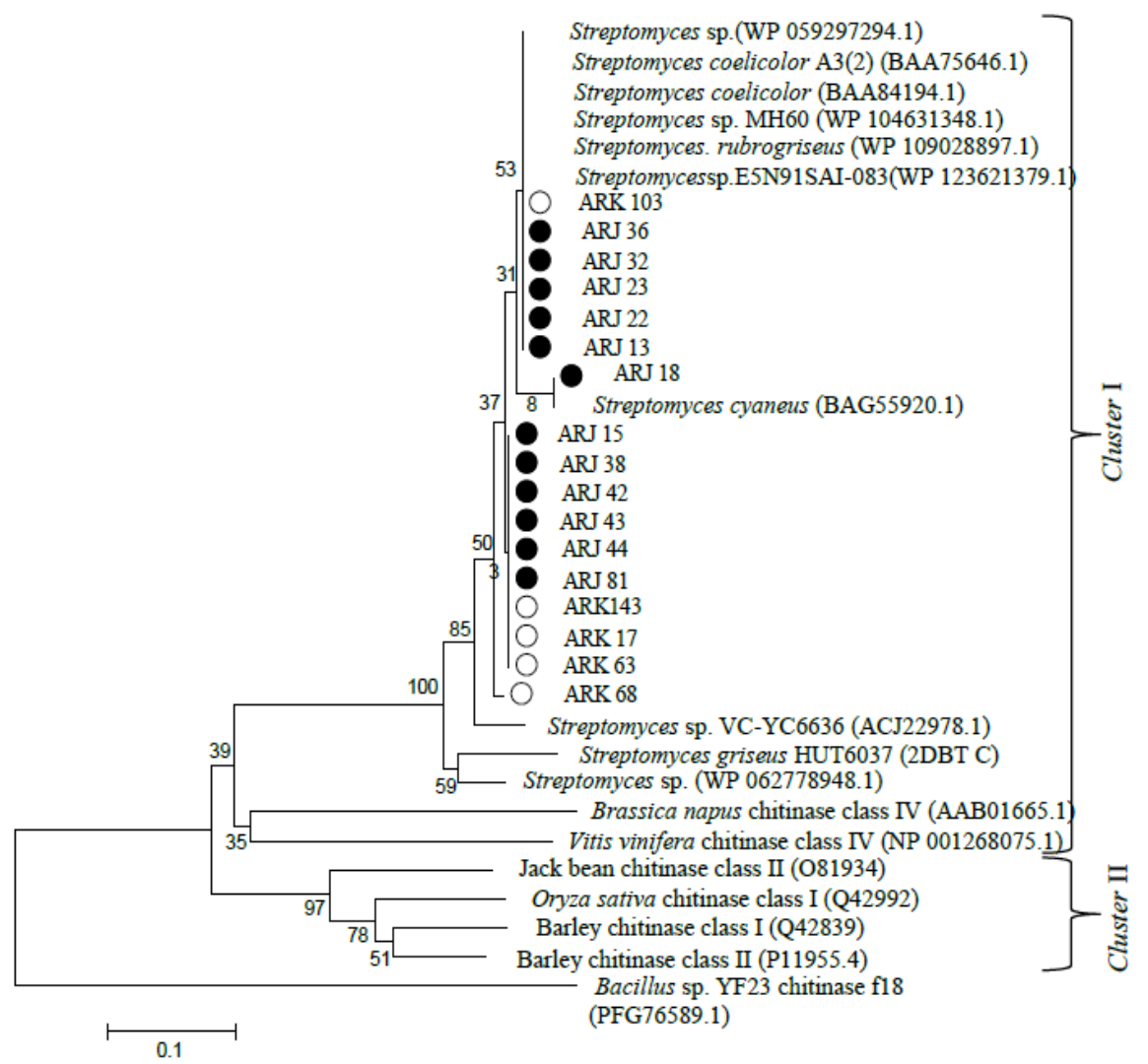

Figure 4. Phylogenetic tree based on amino acid sequences of family 19 chitinases 


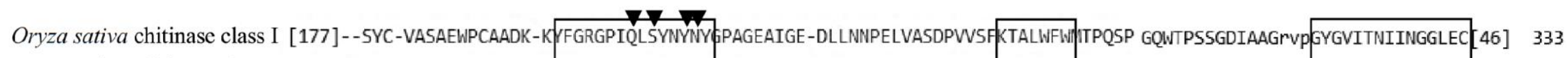
Barley chitinase class I [173]--DVC-QPSSQWPCVQDR-Q|VGRGPIMLSWNYNY PPAGRAIGV-DLLNNPDLVATDATVSFRTALWFWNTTPQAN GOWTPTAADTAAGrvPGYGVITNIINGGLEC [49] 332 Barley chitinase class II [169]--NYC-TPSAQWPCAPGK-S/VGRGPIQLSHNYNY \$PAGRAIGV-DLLRNPDLVATDPTVSFKTAMWFWNTAQAP GQWSPSGTDRAAGrvp GFGVITNIVNGGIEC [39] 318

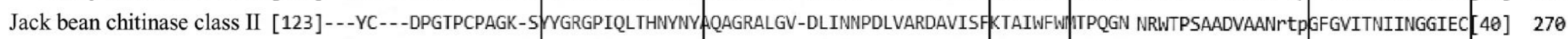

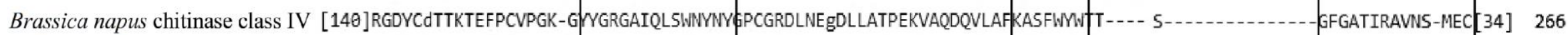

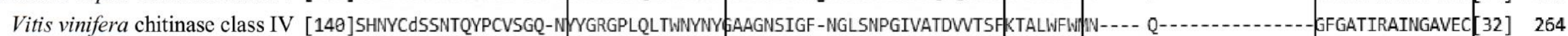

ARJ 13 YPHYC-D*HQPYGCPAGHAD VYGRGPIQLSWNFNY KAAGDALGI-DLLGNPWLVQNDAAVAUKTGLWWWITQSGP GTMTPHDAMVNGA---GFGQTIRSING----

ARJ 15 YPHYC-DXNQPYGCPAGHAD|VGGRPIQLSWNFNYKAAGDALGI-DLLGNPWLVQNDAAVAXKTGLWWWIITQTGP GTMTPHNAMVNGA---GFGOTIRSINGAL 97

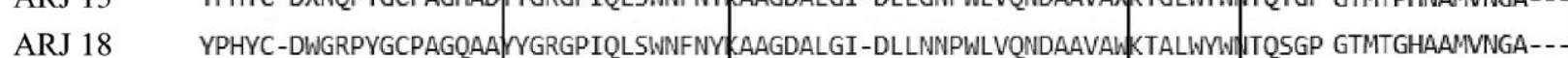

ARJ 22 YPHYC-DWNQPYGCPAGQAATYGGRGIQLSWNFNY KAAGDALGI-DLLGNPWLVQNDAAVAUKTGLWWN|TQSGP GTMTPHNAMVNGA--101

ARJ 23 YPHYC-DWNQPYGCPAGQAAIVGRGPIQLSWNFNYKAAGDALGI-DLLGNPWLVQNDAAVALKTGLWWNITQSGP GTMTPHNAMVNGA---

ARJ 32 YPHYC-DWNQPYGCPAGQAA IYYGRGPIQLSWNFNY KAAGDALGI-DLLGNPWLVQNDAAVAUKTGLWWWITQSGP GTMTPHNAMVNGA--GFGQTIRSINGALEC 1$] 102$

ARJ 36 - - - QPYGCPAGQAA IVGRGPIQLSWNFNYKAAGDALGI-DLLGNPWLVQNDAAVAVKTGLWWNITQSGP GTMTPHNAMVNGA--100

ARJ 38 [ 2]YPHYC-DWXQPYGCPAGHAATYGRGPIQLSWNFNY KAAGDALGI-DLLGNPWLVONDAAVAWKTGLWWN/TQTGP GTMTPHNAMVNGA--ARJ 42 YPHYC-DXXQPYGCPAGHAD|YYGGGIQLSWNFNYKAAGDALGI-DLLGNPWLVQNDAAVAWKTGLWWN|WTTGP GTMTPHNAMVNGA--ARJ 43 YPHYC-DWNQPYGCPAGHAD VYGGGPIQLSWNFNY KAAGDALGI-DLLGNPWLVQNDAAVALKTGLWMNITQTGP GTMTPHNAMVNGA--ARJ 44 YPHYC-DWHQPYGCPAGHDD YYGGRGIQLSWNFNYKAAGDALGI-DLLGNPWLVQNDAAVALKTGLWWNITQTGP GTMTPHNAMVNGA--ARJ 81 [ 2]YPHYC-DWNQPYGCPAGHDD VYGRGPIQLSWNFNYKAAGDALGI-DLLGNPWLVQNDAAVALKTGLWWN|TQTGP GTMTPHNAMVNGA---

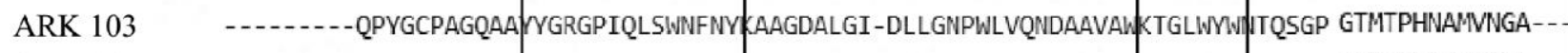
ARK 143 YPHYC-DWNQPYGCPAGHAD|YYGRGPIQLSWNFNYKAAGDALGI-DLLGNPWLVQNDAAVALKTGLWMWITQTGP GTMTPHNAMVNGA--ARK 17 [ 6] LPALL-RLHQPYGCPAGHAD $Y$ YGRGPIQLSWNFNY KAAGDALGI-DLLGNPWLVQNDAAVAW KTGLWWW|TQTGP GTMTPHDAMVNGA--ARK 63 - 63 . ARK 68 Streptomyces griseus HUT 6037 [132] YPHYC-DTTQSYGCPAGQAA VYGRGPIQLSWNFNY KAAGDALGI-NLLANPYLVEQDPAVAUKTGLWWN|ISQNGP GTMTPHNATVNNA--Streptomyces sp. [163]YPHYC-DANQPYGCPAGQAA YYGRGPIQLSINFNYKAAGDALGI-DLLRNPYLVERDPAVAnKTGLWMN.TQSGP GTMTPHNAMVNGK-- 


\section{Discussion}

Chitinase-producing actinomycetes is a potential biocontrol agent against phytopathogenic fungi. Seventeen isolates originated from soybean and maize rhizosphere were able to degrade chitin in vitro. Clear zone formed around the colony indicated chitin hydrolysis by chitinase enzyme. Chitin polymer is broken down into simpler $\mathrm{N}$ acetyl-D-glucosamine (NAG) monomers as nutrition source (Orinda et al. 2015). Colloidal chitin is the most widely used substrate in microbial screening of chitinolytic activities. The types of chitinase that hydrolyse soluble colloidal chitin are generally originated from family 18 and 19. Family 18 chitinase hydrolyzed efficiently crystalline chitin forms, while family 19 chitinase was more efficient to hydrolyze soluble chitin oligomers and have higher antifungal activity than family 18 chitinase (LacombeHarvey et al. 2018). The chitinolytic activity of each isolate varied with the chitinolytic index ranging from $0.49 \pm 0.01$ $2.15 \pm 0.69$. Differences in the chitinolytic index could be used as indicator to specify the types of chitinase. Six isolates with the highest chitinase index from maize and soybean rhizosphere were ARJ 36, ARJ 81, ARJ 15, ARK 17, ARK 143, ARK 103. Chitinase activity of six selected isolates was quantitatively measured based on the amount of NAG produced by the hydrolysis of chitin in liquid medium. One unit of chitinase activity is defined as the amount of enzyme needed to produce $1 \mu \mathrm{mol}$ of NAG per minute (Das et al. 2017).

The difference in qualitatively and quantitatively activity level shows that the chitinase of each isolate has varying ability to hydrolyze chitin. This indicates chitinase produced by each isolate has different characteristics. Each enzyme has specific optimum physical and chemical conditions. Several factors influencing chitinase activity are temperature, $\mathrm{pH}$, type of substrate, substrate concentration, and incubation period (Golinska and Dahm 2011; Das et al. 2017; Chrisnasari et al. 2016). Higher temperature increases kinetic energy between enzyme molecules and substrate accelerating the reaction. However, temperature higher than the optimum limit can change the structure of enzyme active site or even denature the enzyme protein. Acidity also affects enzyme reactions, modifying electrostatic bonds between enzymes and substrate. The incubation period determines the amount of enzyme concentration reacted with the substrate which also affects the enzyme activity. According to Das et al. (2017), the optimum activity of chitinase from soil actinomycetes (coded as 130) occurred at $\mathrm{pH} 8-8.5$, temperature $25-35^{\circ} \mathrm{C}$, substrate concentration $1-1.5 \%$. Shivalee et al. (2016) reported the optimum activity of actinomycetes chitinase occurred in incubation period of 48 hours. Another study stated the optimum activity of chitinase Streptomyces violascens NRRL B2700 was reached at 72 hours of incubation period (Gangwar et al. 2016).

Seventeen rhizosphere actinomycetes isolates with chitinase activity were confirmed by the presence of family 19 chitinase gene. Chitinase gene of isolates was similar to the chitinase gene from the genus Streptomyces with a similarities of $86-99.01 \%$ at the amino acid level. Ten actinomycetes isolates with less than $97 \%$ similarity indicated high variation in amino acid sequences than in the database. Stackebrandt and Goebel (1994) stated that $\geq 3 \%$ differences is categorized as fairly high variation. The 10 isolates were assumed to be new types of family 19 chitinase.

The amplified chitinase gene is a partial sequence of the whole chitinase gene i.e. $\sim 933$ bp (Yano et al. 2021). Family 19 chitinases especially bacterial chitinase contain 3 functional domains, such as chitin-binding domain, catalytic domain, and fibronectin type III (FN3) domain (Malecki et al. 2020). Nucleotide sequences are translated into 81-104 amino acids sequences which is part of the catalytic domain consisted of 203 amino acids (Yano et al. 2021). Amino acids sequences alignment showed the presence of conserved region $\mathrm{C} 2, \mathrm{C} 3$, and $\mathrm{C} 4$. Those regions are 3 out of 4 most conserved area of family 19 chitinase catalytic domain reported by Kawase et al. (2004). Amino acid residues Glu ${ }^{67}, \mathrm{Glu}^{89}, \mathrm{Gln}^{118}$, Tyr ${ }^{123}$, $\mathrm{Asn}^{124}$ in Barley class II endochitinase play an important role in enzyme catalytic activity (Andersen et al. 1997). Mutations in these amino acids can reduce the activity of catalytic enzymes and decrease antifungal activity. The effect of mutations that occurs in the amino acid $\mathrm{Tyr}^{123}$ to $\mathrm{Phe}^{123}$ in the sequences of isolates and $S$. griseus sequences are not yet known. $\mathrm{Tyr}^{123}$ may not be essential but related to some functional importance. $\operatorname{Gln}^{118}$ and $\mathrm{Asn}^{124}$ are proposed to be important in substrate binding (Andersen et al. 1997). In jack bean class II chitinase, Glu ${ }^{90}$ and $\mathrm{Thr}^{119}$ form hydrogen bonds with water molecule which assumed to be involved in the single-displacement inverting reaction mechanism of family 19 chitinase. The position of $\mathrm{Thr}^{119}$ can be replaced by Ser in other family 19 chitinase without altering the catalytic reaction (Kawase et al. 2004). Consistent to this, in all isolates, Ser was found in the corresponding position instead of $\mathrm{Thr}^{119}$. Cys residues form sulfide bond in 3D structure was present in the sequence of isolates.

Based on amino acid sequences of catalytic domain, isolates of the family 19 chitinase gene have closer evolutionary relationship with class IV chitinase (Brassica napus and Vitis vinifera) than class I and II chitinases. The amino acid sequences of catalytic domain of bacteria chitinase are similar to those of plants chitinases class IV (Okazaki et al. 2004). Catalytic domain sequences of chitinase family 19 have a significant difference to family 18 chitinase. Isolates in the first branch have high similarity between these isolates. Similarity sequences can occur because chitinase sequences actually originate from the same species or have less mutations that occur in family 19 chitinase. It was assumed that family 19 chitinase genes were first obtained by the genus Streptomyces and then spread to other actinomycetes through horizontal gene transfer (Prakash et al. 2010).

In this study, 17 isolates of actinomycetes isolated from both maize and soybean rhizosphere, had different chitinolytic activities. The activity and genetic diversity of family 19 chitinase complete gene is interesting to be studied further, considering its potential as biocontrol agent 
against phytopathogenic fungi. Chitinase-producing actinomycetes isolates are expected to be an alternative solution in increasing sustainable agricultural productivity.

\section{ACKNOWLEDGEMENTS}

This work was financially supported by University Exellence-Basic Research ("Penelitian Dasar-Unggulan Perguruan Tinggi"/PD-UPT) from The Ministry of Research and Technology /National Research and Innovation Agency of the Republic of Indonesia 2020 [Contract No.: 1/E1/KP.PTNBH/2020] and 2021 [1/E1/KP.PTNBH/2021] to ATW. The authors thank for all the support to complete this research.

\section{REFERENCES}

Andersen MD, Jensen A, Robertus JD, Leah R, Skriver K. 1997. Heterologous expression and characterization of wild-type and mutant forms of a $26 \mathrm{kDa}$ endochitinase from barley (Hordeum vulgare L.). Biochem J 322: 815-822. DOI: 10.1042/bj3220815

Anwar S, Ali B, Sajid I. 2016. Screening of rhizospheric Actinomycetes for various in-vitro and in-vivo plant growth promoting (PGP) traits and for agroactive compounds. Front Microbiol 7: 1334. DOI: 10.3389/fmicb.2016.01334

Beauvais A, Latge JP. 2018. Special issue: Fungal cell wall. J Fungi 4 (91): 1-8. DOI: 10.3390/jof4030091

Berini F, Presti I, Beltrametti F, Pedroli M, Varum KM, Pollegioni L, Sjoling S, Marinelli F. 2017. Production and characterization of a novel antifungal chitinase identified by functional screening of a suppressive-soil metagenome. Microb Cell Fact 16 (16): 1-15. DOI: 10.1186/s12934-017-0634-8

Brzezinska MS, Jankiewicz U, Burkowska A, Walczak M. 2014 Chitinolytic microorganisms and their possible application in environmental protection. Curr Microbiol 68 :71-81. DOI: 10.1007/s00284-013-0440-4

Chrisnasari R, Yasaputera S, Christianto P. 2016. Production and characterization of chitinases from thermophilic bacteria isolated from Prataan Hot Spring, East Java. J Math Fund Sci 48 (2): 149-163. DOI: 10.5614/j.math.fund.sci.2016.48.2.6

Das P, Kumar P, Kumar M, Solanki R, Kapur MK. 2017. Purification and molecular characterization of chitinases from soil Actinomycetes. Afr J Microbiol Res 11 (27): 1086-1102. DOI: 10.5897/AJMR2017.8612

Dawood ES, Mohamed AA. 2015. Isolation and screening of different chitinolytic mycoflora isolated from sudanese soil for biological control of Fusarium oxysporium. Asian J Agr Food Sci 3(4): 412-418.

Gangwar M, Singh V, Pandey AK, Tripathi CKM, Mishra BN. 2016. Purification and characterization of chitinase from Streptomyces violascens NRRL B2700. Ind J Exp Biol 54: 64-71.

Gherbawy Y, Elhariry H, Altalhi A, El-DeeB B, Khiralla G. 2012. Molecular screening of Streptomyces isolates for antifungal activity and family 19 chitinase enzymes. J Microbiol 50 (3): 459-468. DOI: 10.1007/s12275-012-2095-4

Glesiandra C. 2016. Penghambatan pertumbuhan Pyricularia oryzae oleh aktinomiset filosfer padi penghasil kitinase. [Thesis]. Bogor: Departemen Biologi, Institut Pertanian Bogor. [Indonesian]

Golinska P, Dahm H. 2011. Enzymatic activity of Actinomycetes from the genus Streptomyces isolated from the bulk soil and rhizosphere of the Pinus sylvestris. Dendrobiol 65: 37-46.
Gopalakrishnan S, Vadlamudi S, Samineni S, Kumar CS. 2016. Plant growth-promotion and biofortification of chickpea and pigeonpea through inoculation of biocontrol potential bacteria, isolated from organic soils. SpringerPlus 5 (1): 1882. DOI: 10.1186/s40064-0163590-6

Kawase T, Saito A, Sato T, Kanai R, Fujii T, Nikaidou, Miyashita K, Watanabe T. 2004. Distribution and phylogenetic analysis of family 19 chitinases in Actinobacteria. App Environ Microbiol 70 (2): 1135 1144. DOI: 10.1128/AEM.70.2.1135-1144.2004

Lacombe-Harvey ME, Brzezinski R, Beaulieu C. 2018. Chitinolytic functions in actinobacteria: Ecology, enzymes, and evolution. App Microbiol Biotech 102 (1): 7219-7230. DOI: 10.1007/s00253-0189149-4

Malecki PH, Bejger M, Rypniewski W, Vorgias CE. 2020. The crystal structure of a Streptomyces thermoviolaceus thermophilic chitinase known for its refolding efficiency. Mol Sci 21 (8): 2892. DOI: 10.3390/ijms21082892

Mariastuti HD, Listiyowati S, Wahyudi AT. 2018. Antifungal activity of soybean rhizosphere Actinomycetes producing bioactive compounds against Fussarium oxysporum. Biodiversitas 19 (6): 2127-1233. DOI: 10.13057/biodiv/d190619

Okazaki K, Yamashita Y, Noda M, Suetoshi N, Kameshita I, Hayakawa S. 2004. Molecular cloning and expression of the gene encoding family 19 chitinase from Streptomyces sp. J-13-3. Biosci Biotechnol Biochem 68 (2): 341-351. DOI: 10.1271/bbb.68.341

Orinda E, Puspita ID, Putra MP, Ustadi, Lelana IYB. 2015. Chitinolytic enzyme activity of isolate SDI23 from petis and the activity of its partially purified enzyme in different $\mathrm{pH}$ and temperature. J Fish Sci 17 (2): 96-102.

Oyeleye A, Normi YM. 2018. Chitinase: Diversity, limitations, and trends in engineering for suitable applications. Biosci Rep 38 (4): 1-54. DOI: 10.1042/BSR20180323

Shivalee A, Divatar M, Sandhya G, Ahmed S, Lingappa K. 2016. Isolation and screening of soil microbes for extracellular chitinase activity. J Adv Sci Res 7 (2): 10-14.

Singh R, Upadhyay SK, Singh M, Sharma I, Sharma P, Kamboj P, Saini A, Voraha R, Sharma AK, Upadhyay TK, Khan F. 2021. Chitin, chitinases and chitin derivatives in biopharmaceutical, agricultural and environmental perspective. Bio Res in App Chem 11 (3): 998510005. DOI: 10.33263/BRIAC113.998510005

Stackebrandt E, Goebel BM. 1994. Taxonomic note: A place for DNADNA reassociation and $16 \mathrm{~S}$ rRNA sequence analysis in the present species definition in bacteriology. Int J Sys Bacteriol 44: 846-849. DOI: 10.1099/00207713-44-4-846

Prakash NAU, Jayanthi M, Sabarinathan R, Kangueane P, Mathew L, Sekar K. 2010. Evolution, homology conservation, and identification of unique sequence signatures in GH19 family chitinases. J Mol Evol 70 (5): 466-478. DOI: 10.1007/s00239-010-9345-Z

Vejan P, Abdullah R, Khadiran T, Ismail S, Boyce AN. 2016. Role of plant growth promoting rhizobacteria in agricultural sustainability. Molecules 21 (5): 573. DOI: 10.3390/molecules21050573

Veliz EA, Hidalgo PM, Hirsch AM. 2017. Chitinase-producing bacteria and their role in biocontrol. AIMS Microb 3 (3): 689-705. DOI: 10.3934/microbiol.2017.3.689

Wahyudi AT, Priyanto JA, Fijrina HN, Mariastuti HD, Nawangsih AA. 2019a. Streptomyces spp. from rhizosphere soil of maize with potential as plant growth promoter. Biodiversitas 20 (9): 2547-2553. DOI: $10.13057 /$ biodiv/d200916

Wahyudi AT, Priyanto JA, Afrista R, Kurniati D, Astuti RI, Akhdiya A. 2019 b. Plant growth promoting activity of Actinomycetes isolated from soybean rhizosphere. J Biol Sci 19 (1): 1-8. DOI: 10.3844/ojbsci.2019.1.8

Yano S, Kanno H, Tsuhako H, Ogasawara S, Suyotha W, Konno H, Makabe K, Uechi K, Taira T. 2021. Cloning, expression, and characterization of a GH19-type chitinase with antifungal activity from Lysobacter sp. Mk9-1. J Biosci Bioeng 131 (4): 348-355. DOI: 10.1016/j.jbiosc.2020.11.005 